\title{
Antioxidant Activity, Total Phenolic, Flavonoid and Saponin Contents of Different Solvent Extracts of Convolvulus phrygius Bornm.
}

\author{
Cennet Ozay*, Ramazan Mammadov \\ Department of Biology, Pamukkale University, 20070, Denizli, Turkey \\ *Correspondence: cennetozay@hotmail.com, (Cennet Ozay)
}

Published: 29 July 2019

\begin{abstract}
It is known that some members of the genus Convolvulus L. are commonly used in Turkish folk medicine. These species are powerful in curing the toothache and joint pains. This study was focused on the determination of the total phenolic, flavonoid and saponin contents of the different solvent (methanol, acetone and petroleum benzine) extracts of Convolvulus phrygius as well as its antioxidant activity. FolinCiocalteu assay, aluminium colorimetric and vanillin-sulphuric acid method were used to detect total phenolic, flavonoid and saponin contents in the extracts, respectively. The antioxidant activities were determined by using ABTS, NO, FRAP, phosphomolybdenum, and metal chelating methods. The methanol extract of $C$. phrygius demonstrated highest antioxidant and total phenolic, flavonoid and saponin content. Our results showed that $C$. phrygius could be accepted as a novel and alternative natural antioxidant source. Further studies should be carried out on the identification of responsible active components.
\end{abstract}

Key words: Convolvulus phrygius, antioxidant activity, bioactive compounds

\section{Introduction}

As shown in recent years, natural antioxidants discovered in plants have attracted some interest due to their widely acclaimed nutritional and therapeutic values. Antioxidant properties stand to be an essential mechanism of beneficial activity of plant-derived compounds and extracts (Khorasani Esmaeili et al., 2015). Ethnopharmacological surveys have shed light on the fact that the therapeutic use of even $80 \%$ of 122 plant-derived drugs may have a link with their recommendations in traditional medicine (Fabricant and Farnsworth, 2001). Natural antioxidants have a diversity of biochemical activities, some of which include the inhibition of reactive oxygen species (ROS) generation, direct or indirect scavenging of free radicals, and alteration of intracellular redox potential (Finkel and Holbrook, 2000).

Studies regarding the bioactivities of various plants have assumed an important position because of the variations in the effectiveness of the plant extract with the solvent for extraction used, plant part used, the plants' age, and geographic origin (Khorasani Esmaeili et al., 2015). The genus Convolvulus L. belongs to Convolvulaceae family, including 250 taxa, generally recognized as bindweeds. With respect to recent researches, this genus is represented with 39 taxa (three of them hybrids) in Turkey (Aykurt, 2010). Some taxa of this genus are used in the treatment of toothache (Altundag and Ozturk, 2011) and also as anthelminthic, laxative and cholagogue (Baytop, 1999) in Turkish folk medicine. C. phrygius, which is endemic to Turkey, is categorized as "Near Threatened" 
(NT) by the International Union for Conservation of Nature (IUCN) (Aykurt and Sümbül, 2014). Extracts of various members of Convolvulus have been demonstrated to have antioxidant activities (Rachitha et al., 2018; Benmerache et al., 2013). Although, some studies have been performed on the phytochemicals and biological activities of $\mathrm{C}$. arvensis, C. pluricaulis and C. fatmensis (Elzaawely and Tawata, 2012; Azman et al., 2015; Gupta and Fernandes, 2019; Rachitha et al., 2018), the study about C. phrygius is very limited. Therefore, the objective of this research was to reveal the antioxidant potentials and total bioactive compounds (total phenolics, flavonoids and saponins) of endemic $C$. phrygius.

\section{Material and Methods}

Plant material and extraction: The individuals of $C$. phrygius Bornm. were collected in Korkuteli/Antalya-Turkey from the environs of the Korkuteli Dam, open slopes, 1250 m, June 2008. Taxonomic identification of the plant was confirmed by the senior taxonomist Dr. Candan Aykurt, in Department of Biology, Akdeniz University, Antalya-Turkey. The voucher specimen was deposited at the Akdeniz University Herbarium (Voucher no: C. Aykurt 2055). The plants were air-dried and their aerial parts were powderized. Methanol, acetone and petroleum benzine were used for the extraction in a shaker water bath for 6 hours at $55^{\circ} \mathrm{C}$ (Ozay et al., 2015). The extracts were filtered and vaporized by using rotary evaporator and then lyophilized. The crude extracts were kept at $+4^{\circ} \mathrm{C}$ until needed.

Total phenolic, flavonoid and saponin contents: The phenolic, flavonoid and saponin contents of the plant extracts were determined by using the Folin-Ciocalteu protocol (Slinkard and Singleton, 1977), $\mathrm{AlCl}_{3}$ (Moreno et al., 2000) and vanillin-sulphuric acid (Hiai et al., 1976) colorimetric methods, respectively. These contents were expressed as gallic acid (mg GAEs/g), quercetin (mg QEs/g) and quillaja (mg QAEs/g) equivalents, respectively.

\section{Antioxidant activity assays}

Ferric reducing antioxidant power (FRAP) assay: Ferric reducing antioxidant power assay was applied as described by Zengin et al. (2014) with some modifications. Extract solutions was added to FRAP reagent which mixed in advance (acetate buffer- $0.3 \mathrm{M}$, TPTZ (2,4,6-tripyridyl-s-triazine- $10 \mathrm{mM}$, FeCI3- $20 \mathrm{mM}$ ). After measuring the absorbances at $593 \mathrm{~nm}$, FRAP activity was expressed as trolox (mg TEs/g extract) equivalents.

Total antioxidant capacity (Phosphomolybdenum method): Phosphomolybdenum method was used to evaluate total antioxidant capacity of the extracts Briefly, different extract solutions were mixed with the reagent solution $\left(0.6 \mathrm{M} \mathrm{H}_{2} \mathrm{SO}_{4}, 28 \mathrm{mM} \mathrm{Na}_{3} \mathrm{PO}_{4}\right.$ and $\left.4 \mathrm{mM}\left(\mathrm{NH}_{4}\right) 2 \mathrm{MoO}_{4}\right)$, and incubated for $90 \mathrm{~min}$ at $95^{\circ} \mathrm{C}$. The absorbance values were determined at $695 \mathrm{~nm}$ wavelength (Berk et al., 2011). Total antioxidant capacity was expressed as trolox (mmol TEs/g extract) equivalents.

Metal chelating activity: Extract solutions at different concentrations were added to $\mathrm{FeCl} 2(0.05 \mathrm{~mL}, 2 \mathrm{mM})$. The reaction that started directly after adding $5 \mathrm{mM}$ of ferrozine was measured at $562 \mathrm{~nm}$ after $10 \mathrm{~min}$ left at room temperature. Metal chelating activity was expressed as EDTA (mg EDTAEs/g extract) equivalents. (Zengin et al., 2015). 
NO (Nitric oxide) scavenging activity: NO was produced from sodium nitroprusside (SNP) which measured as described by Balakrishnan et al. (2009) by using the Griess reaction. The mixture containing SNP (5mM) in PBS (pH 7.3), with the extracts were prepared in PBS at different concentrations and incubated for 3 hours at $25^{\circ} \mathrm{C}$. The absorbance value was determined at $546 \mathrm{~nm}$ wavelength. Ascorbic acid was used as a positive control. The results were indicated as $\mathrm{IC}_{50}$.

ABTS (2,2 azino-bis (3-ethylbenzothiazloine-6-sulfonic acid)) radical scavenging activity: The scavenging activity towards ABTS radical was analyzed as described by $\mathrm{Re}$ et al. (1999) with some modifications. Freshly prepared and diluted ABTS solution were mixed with the various solvent extracts of $C$. phrygius and the absorbances were read after $30 \mathrm{~min}$ at $734 \mathrm{~nm}$. The results were indicated as $\mathrm{IC}_{50}$.

Statistical analysis: Statistical analysis was performed using the software SPSS version 22.0 program. Statistical significance was determined using the one-way ANOVA. Multiple group comparisons were analyzed with Tukey's multiple comparison test. Data were expressed as a mean \pm SD. $p$ value of $<0.05$ was considered to be statistically significant.

\section{Results and Discussion}

Total phenolic, flavonoid and saponin contents: Being plant secondary metabolites, the phenolics or polyphenols are very significant judging from the virtue of their antioxidant activities by chelating redox-active metal ions, inactivating lipid free radical chains, and avoiding the hydroperoxide conversions into reactive oxyradicals. Being widely distributed amongst plants, saponins have long been regarded as phytochemical material to protect plant against pathogens. Therefore, it is no doubt that saponins function as potential medicinal candidates (Khorasani Esmaeili et al., 2015; Hassan et al., 2013). The total phenolic, flavonoid and saponin contents (TPC, TFC and TSC) of the methanol, acetone and petroleum benzine extracts of C. phrygius were investigated with spectrophotometric methods and the results are presented in Table 1.

Table 1. Total phenolic, flavonoid and saponin contents of $C$. phrygius extracts (mean \pm SD).

\begin{tabular}{lccc}
\hline Solvent & TPC $^{\mathbf{a}}$ & TFC $^{\mathbf{b}}$ & TSC $^{\mathbf{c}}$ \\
\hline Petroleum benzine & $12.01 \pm 0.03$ & $06.54 \pm 0.01$ & $22.01 \pm 0.06$ \\
Acetone & $33.07 \pm 0.08$ & $11.02 \pm 0.03$ & $54.05 \pm 0.09$ \\
Methanol & $74.32 \pm 1.02$ & $35.42 \pm 0.05$ & $91.35 \pm 1.23$ \\
\hline
\end{tabular}

aTotal phenolic content (TPC) expressed as gallic acid equivalents (mg GAEs/g).

bTotal flavonoid content (TFC) expressed as quercetin equivalents (mg QEs/g)

cTotal saponin content (TSC) expressed as quillaja equivalents (mg QAEs/g)

According to the obtained data, the total phenolic content (74.32 mg GAEs/g), total flavonoid content (35.42 mg QEs/g) and total saponin content (91.35 mg QAEs/g) were detected to be at highest in the methanol extract of the plant. Alkaloids, flavonoids, coumarins, sterols, saponins and tannins have been isolated from plants of the genus Convolvulus L. (Todd et al., 1995; Menemen et al., 2002). The total phenolic and flavonoid content of Convolvulus galaticus were reported earlier as $84.689 \mathrm{mg}$ GAEs/g and 48.760 mg CEs/g, respectively (Türker and Yıldırım, 2018). Elzaawely and Tawata (2012) found the total phenolic and flavonoid content of Convolvulus arvensis leaves as $244.6 \mathrm{mg}$ $\mathrm{GAE} / \mathrm{g}$ and $174.4 \mathrm{mg} \mathrm{RE} / \mathrm{g}$, respectively. Despite having various amounts of bioactive 
compounds as a result of using different taxa, solvents and growing conditions, it would not be surprising to say that most of these Convolvulus taxa could be a significant source of phenolic compounds.

Antioxidant activity: Antioxidants convert reactive oxygen species to non-toxic products and stop or eliminate the side effects of reactive oxygen species, prevent some disorders, such as cancer, cardiovascular diseases, diabetes, infections and ischemia (Al-Dabbas, 2017). The use of only one method does not reflect the antioxidant activity of plant extracts due to complicated structure of bioactive secondary metabolites (Du et al., 2009). Hence, chiefly five methods were used in order to detect the antioxidant activity of C. phrygius with different solvents. The outcomes of free radical scavenging assay (ABTS and NO), phosphomolybdenum, metal chelating and ferric reducing power assays are presented in Table $2(\mathrm{p}<0.05)$.

Table 2. Antioxidant activities of $C$. phrygius extracts (mean \pm SD).

\begin{tabular}{|c|c|c|c|c|c|}
\hline Solvent & $\begin{array}{c}\text { ABTS } \\
\left(\mathrm{IC}_{50} \mu \mathrm{g} / \mathrm{mL}\right)\end{array}$ & $\begin{array}{c}\text { NO } \\
\left(\mathrm{IC}_{50} \mu \mathrm{g} / \mathrm{mL}\right)\end{array}$ & $\begin{array}{c}\text { FRAP } \\
\text { assay } \\
\text { (mg TEs } / g \text { ) } \\
\end{array}$ & $\begin{array}{c}\text { Phosphomolybdenum } \\
\text { assay } \\
\text { (mmol TEs/g) }\end{array}$ & $\begin{array}{l}\text { Metal chelating } \\
\text { activity } \\
\text { (mg EDTAEs/g) }\end{array}$ \\
\hline $\begin{array}{l}\text { Petroleum } \\
\text { benzine }\end{array}$ & $97.25 \pm 1.77^{\mathrm{a}}$ & $81.58 \pm 1.55^{a}$ & $32.04 \pm 0.10^{c}$ & $0.28 \pm 0.01^{\mathrm{b}}$ & $03.11 \pm 0.01^{\mathrm{b}}$ \\
\hline Acetone & $66.05 \pm 1.12^{\mathrm{b}}$ & $60.21 \pm 0.06^{b}$ & $51.03 \pm 0.05^{\mathrm{b}}$ & $1.26 \pm 0.08^{a}$ & $14.02 \pm 0.02^{\mathrm{a}}$ \\
\hline Methanol & $38.44 \pm 0.07 \mathrm{c}$ & $44.55 \pm 0.17 \mathrm{c}$ & $74.19 \pm 1.06^{\mathrm{a}}$ & $1.95 \pm 0.09 a$ & $22.07 \pm 0.04^{a}$ \\
\hline Ascorbic acid & $08.48 \pm 0.01^{\mathrm{d}}$ & $17.01 \pm 0.04^{\mathrm{d}}$ & nt & nt & nt \\
\hline
\end{tabular}

Thrakal et al. (2010) reported that the IC50 values obtained from the DPPH and NO assays in C. arvensis methanolic extracts were determined as 131.03 and $130.12 \mu \mathrm{g} / \mathrm{mL}$, respectively and the researcher found that phenolic compounds such as phenolic acids, flavonoids, and tannins, which found in C. arvensis, could be the responsible compounds for antioxidant activity. In the current study, the highest scavenging activity values obtained from the NO $(44.55 \mu \mathrm{g} / \mathrm{mL})$ and ABTS $(38.44 \mu \mathrm{g} / \mathrm{mL})$ assays were detected by methanol extracts. Total antioxidant capacity of extracts was examined by phosphomolybdenum method, which measures phenolic and non-phenolic compounds related to their reductive activity. The methanolic extracts of $\mathrm{C}$. phrygius demonstrated the most powerful total antioxidant activity as $1.95 \mathrm{mmol}$ TEs/g (Table 2) ( $<<0.05)$. The studied extracts exhibited satisfactory correlation with their TPC, TFC and TSC. In this context, total antioxidant capacity could be depicted by the presence of bioactive compounds. C. phrygius methanolic extracts showed the strongest FRAP activity with $74.19 \mathrm{mg}$ TEs/g, whereas the lowest activity was found in petroleum benzine extracts as $32.04 \mathrm{mg}$ TEs/g. In conformity with outcomes of other antioxidant tests, effective chelation power was again determined in the methanol extract with $22.07 \mathrm{mg}$ EDTAEs/g. The results showed that major phytochemicals in C. phrygius were polar properties extracted by methanol, which was determined to be the most potent on antioxidant activity, including phenolics and saponins.

\section{Conclusion}

In conclusion, this research notifies for the first time the antioxidant and total phenolic, flavonoid and saponin contents of C. phrygius. It can be proposed that the observed antioxidant activity of the C. phrygius extract can be ascribed to the existence of these bioactive compounds. Although this is the first study carried out on this plant, further in- 
vitro and in-vivo studies are needed in order to better understand the potential of this plant.

\section{References}

Al-Dabbas, M.M., 2017. Antioxdant activity of different extracts from the aerial part of Moringa peregrina (Forssk.) Fiori, from Jordan. Pakistan Journal of Pharmaceutical Sciences 30, 2151-2157.

Altundag, E., Ozturk, M., 2011. Ethnomedicinal studies on the plant resources of east Anatolia, Turkey. Procedia Social and Behavioral Sciences 19, 756-777.

Aykurt, C., 2010. Taxonomical studies on genus Convolvulus L. (Convolvulaceae) in Turkey. PhD thesis, Univ. of Akdeniz.

Aykurt, C., Sümbül, H., 2014. Taxonomic revision of the genus Convolvulus L. (Convolvulaceae) in Turkey. Biological Diversity and Conservation 7, 10-37.

Azman, N.A., Gallego, M.G., Juliá, L., Fajari, L., Almajano, M., 2015. The Effect of Convolvulus arvensis Dried Extract as a Potential Antioxidant in Food Models. Antioxidants 4, 170-184.

Balakrishnan, N., Panda, A.B., Raj, N.R., Shrivastava, A., Prathani, R.B., 2009. The evaluation of nitric oxide scavenging activity of Acalypha indica Linn Root. Asian Journal Research Chemistry 2, 148-150.

Baytop, T., 1999. Türkiye'de Bitkiler ile Tedavi. Nobel Tıp Kitabevleri, İstanbul.

Benmerache, A., Berrehal, D., Kabouche, A., Semra, Z., Thomas, O., Touzani, R., Kabouche, Z., 2013. Antioxidant, antibacterial activities and flavonoids of Convolvulus fatmensis G. Kunze. Der Pharmacia Lettre 5, 371-375.

Berk, S., Tepe, B., Arslan, S., Sarikurkcu, C., 2011. Screening of the antioxidant, antimicrobial and DNA damage protection potentials of the aqueous extract of Asplenium ceterach DC. African Journal of Biotechnology 10, 8902-8908.

Du, G.R., Li, M.J., Ma, F.W., Liang, D., 2009. Antioxidant capacity and the relationship with polyphenol and Vitamin C in Actinidia fruits. Food Chemistry 113, 557-562.

Elzaawely, A.A., Tawata, S., 2012. Antioxidant Activity of Phenolic Rich Fraction Obtained

from Convolvulus arvensis L. Leaves Grown in Egypt. Asian Journal of Crop Science 4, 32-40.

Fabricant, D.S., Farnsworth, N.R., 2001. The value of plants used in traditionalmedicine for drug discovery. Environmental Health Perspectives 109, 69-75.

Finkel, T., Holbrook, N.J., 2000. Oxidants, oxidative stress and the biology of ageing. Nature 408, 239-247.

Gupta, G.L., Fernandes, J., 2019. Protective eff ect of Convolvulus pluricaulis against neuroinflammation associated depressive behavior induced by chronic unpredictable mild stress in rat. Biomedicine and Pharmacotherapy 109, 1698-1708.

Hassan, S.B., Gullbo, J., Hu, K., Berenjian, S., Morein, B., Nygren, P., 2013. The Nanoparticulate Quillaja Saponin BBE is selectively active towards renal cell carcinoma. Anticancer Research 33(1), 143-51.

Hiai, S., Oura, H., Nakajima, T., 1976. Color reaction of some sapogenins and saponins with vanillin and sulfuric acid. Planta Medica 29, 116-122.

Khorasani Esmaeili, A., Mat Taha, R., Mohajer, S., Banisalam, B., 2015. Antioxidant Activity and Total Phenolic and Flavonoid Content of Various Solvent Extracts from In Vivo and In Vitro Grown Trifolium pratense L. (Red Clover). BioMed Research International, 643285. doi:10.1155/2015/643285.

Menemen, Y., Williams, C.A., Jury, S.L., 2002. Flavonoid patterns in Convolvulus L. (Convolvulaceae) species from Morocco. Pakistan Journal of Botany 34, 291-295.

Moreno, M.I., Isla, M.I., Sampietro, A.R., Vattuone, M.A., 2000. Comparison of the free radical-scavenging activity of propolis from several regions of Argentina. Journal of Ethnopharmacology 71, 109-114.

Ozay, C., Mammadov. R., Tasdelen. G., Karagur, E.R., Akca, H., 2015. Potential antioxidant, antiproliferative and hepatoprotective effects of Crataegus meyeri. Journal of Food Biochemistry 39, 548-553.

Rachitha, P., Krupashree, K., Jayashree, G.V., Kandikattu, H.K., Amruta, N., Gopalan, N., Rao, M.K., Khanum, F., 2018. Chemical composition, antioxidant potential, macromolecule damage and neuroprotective activity of Convolvulus pluricaulis. Journal of Traditional and Complementary Medicine 8, 483-496.

Re, R., Pellegrini, N., Proteggente, A., Pannala, A., Yang, M., Rice-Evans, C., 1999. Antioxidant activity applying an improved ABTS radical cation decolorization assay. Free Radical Biology and Medicine 26, 12311237.

Sadeghi-Aliabadi, H., Ghasemi, N., Kohi, M., 2008. Cytotoxic effect of Convolvulus arvensis extracts on human cancerous cell line. Research in Pharmaceutical Sciences 3, 31-34.

Saleem, M., Qadir, M.I., Ahmad, B., Saleem, U., Naseer, F., SchiniKerth, V., Ahmad, M., Hussain, K., 2014. Cytotoxic effect of ethanol extract of Convolvulus arvensis L (Convolvulaceae) on lymphoblastic leukemia Jurkat cells. Tropical Journal of Pharmaceutical Research 13, 705-709. 
Slinkard, K., Singleton, V.L., 1977. Total phenol analyses: automation and comparison with manual methods. American Journal of Enology and Viticulture 28, 49-55.

Thakral, J., Borar, S., Kalia, A.N., 2010. Antioxidant potential fractionation from methanol extract of aerial parts of Convolvulus arvensis Linn. (Convolvulaceae). International Journal of Pharmaceutical Sciences and Drug Research 2, 219-223.

Todd, F.G., Stermitz. F.R., Schultheis, P., Knight, A.P., Traub-Dargatz, J., 1995. Tropane alkaloids and toxicity of Convolvulus arvensis. Phytochemistry 39, 301-303.

Zengin, G., Nithiyanantham, S., Locatelli, M., Ceylan, R., Uysal, S., Aktumsek, A., Selvi, P.K., Maskovic, P., 2015. Screening of in vitro antioxidant and enzyme inhibitory activities of different extracts from two uninvestigated wild plants: Centranthus longiflorus subsp. longiflorus and Cerinthe minor subsp. auriculata. European Journal of Integrative Medicine 8, 286-292.

Zengin, G., Sarikurkcu, C., Aktumsek, A., Ceylan, R., Ceylan, O.A., 2014. Comprehensive study on phytochemical characterization of Haplophyllum myrtifolium Boiss. endemic to Turkey and its inhibitory potential against key enzymes involved in Alzheimer, skin diseases and type II diabetes. Industrial Crops and Products 53, 244-251. 